\title{
Studies into Potassium Management for Sugarcane Production in Northeast Thailand Based on Factory Juice Analysis Combined with Cultivation Experiment
}

\author{
Kenta Watanabe*, Chaiwat Ngasan, Samran Saensupo, Klanarong Sriroth
}

Mitr Phol Sugarcane Research Center Company Limited, Phukhiao, Thailand

Email address:

kentaw19890309@yahoo.co.jp (K. Watanabe)

${ }^{*}$ Corresponding author

\section{To cite this article:}

Kenta Watanabe, Chaiwat Ngasan, Samran Saensupo, Klanarong Sriroth. Studies into Potassium Management for Sugarcane Production in Northeast Thailand Based on Factory Juice Analysis Combined with Cultivation Experiment. American Journal of Agriculture and Forestry. Vol. 7, No. 6, 2019, pp. 239-247. doi: 10.11648/j.ajaf.20190706.11

Received: August 29, 2019; Accepted: September 19, 2019; Published: September 26, 2019

\begin{abstract}
Potassium (K) is one of the essential nutrients for plants; nevertheless, it has been reported that overdoses of $\mathrm{K}$ fertilizer have resulted in impaired sugarcane juice quality and a reduction in the efficiency of sugar processing. Therefore, to maximize sugar production per unit area, $\mathrm{K}$ levels in sugarcane should be kept just adequate. The aim of this study was to propose a practical method of $\mathrm{K}$ fertilizer management based on the nutritional status of sugarcane juice. First, we conducted a pot experiment treating sugarcane with different $\mathrm{K}$ fertilizers (potassium chloride, $\mathrm{KCl}$ and potassium sulfate, $\mathrm{K}_{2} \mathrm{SO}_{4}$ ) and $\mathrm{K}$ rates $\left(0,2,10,30\right.$, and $\left.50 \mathrm{~g} \mathrm{pot}^{-1}\right)$. Raising $\mathrm{KCl}$ rates caused considerably negative impacts on not only the quality but the yield as juice $\mathrm{K}$ concentration exceeded $2000 \mathrm{mg} \mathrm{L}^{-1}$, whereas the effects of the $\mathrm{K}_{2} \mathrm{SO}_{4}$ treatments were less severe. Second, we collected sugarcane juice at a raw sugar factory over 2 years. Because of its ease of measurement, electrical conductivity was used to deduce juice $\mathrm{K}$ concentration. The juice analysis revealed that more than $60 \%$ of the samples possessed $\mathrm{K}$ concentrations higher than $2000 \mathrm{mg} \mathrm{L}^{-1}$, and the relationship between juice $\mathrm{K}$ and sugarcane quality was significantly negative. These results indicate that impairments of sugarcane quality have probably been occurring in the actual fields. Given that sugarcane is generally fertilized with $\mathrm{KCl}$, reducing $\mathrm{K}$ fertilizer dose should contribute to improving sugarcane quality and accordingly sugar yield when juice $\mathrm{K}$ is considered high.
\end{abstract}

Keywords: Sugarcane, Potassium Management, Juice Quality, Sugar Yield, Electrical Conductivity

\section{Introduction}

In sugarcane production, it is necessary to improve juice quality as well as cane yield to maximize sugar production per unit area. Fertilizer management practice is one of the factors that affect sugarcane quality and thus appropriate practices based on the nutritional status of each field are imperative for quality improvement. Potassium $(\mathrm{K})$ is one of the three essential macronutrients for plant growth, along with nitrogen and phosphorus, and plays numerous roles including enzyme activation, stomatal activity, photosynthesis, transport of sugar, water, and nutrient, and synthesis of protein and starch [1]. Bartholomew and Janssen have made an observation that plants absorb considerably more $\mathrm{K}$ than is necessary for the normal processes of growth, known as luxury consumption [2]. Depending on the crop, the $\mathrm{K}$ requirement can be nearly as high as the nitrogen requirement. In fact, sugarcane may remove up to $800 \mathrm{~kg}$ of $\mathrm{K} \mathrm{ha}^{-1}[3]$.

Despite its importance, it has been reported that overdoses of $\mathrm{K}$ fertilizer beyond suitable levels rather lead to lower quality of cane juice $[4,5]$. In addition, on the basis of a hypothesis that sugarcane quality is affected by the accessory components of $\mathrm{K}$ fertilizer as well as $\mathrm{K}$ itself, Watanabe et al. examined the effects of raising $\mathrm{K}$ levels using potassium chloride $(\mathrm{KCl})$ and potassium sulfate $\left(\mathrm{K}_{2} \mathrm{SO}_{4}\right)$ and observed significant sucrose reductions in sugarcane juice with increasing levels of $\mathrm{KCl}$ but not of $\mathrm{K}_{2} \mathrm{SO}_{4}$ [6]. This point was further studied and it was confirmed that the sucrose reduction was caused only when $\mathrm{K}$ was supplied in excess 
amounts combined with chloride in the form of $\mathrm{KCl}$ [7]. These findings are considered noteworthy since the vast majority of crops are fertilized with $\mathrm{KCl}$, actually accounting for more than $90 \%$ of world $\mathrm{K}$ consumption in agriculture [8]. Apart from its adverse impacts on the juice quality, $\mathrm{K}$ is also known to impair sucrose recovery in the process of sugar production, being the most abundant cation in cane juice to the extent that between 30 to $50 \%$ of ash [4]. In sugarcane juice or raw sugar, ash refers to the soluble inorganic salts and increases the solubility of sucrose; therefore, high levels of ash increase sucrose loss during both the milling and refining processes [9]. All these negative aspects suggest that $\mathrm{K}$ in sugarcane should be kept at just adequate levels to optimize juice quality during cultivation and recoverable sugar yield during processing, so that sugar production per unit area is maximized.

In order to perform suitable $\mathrm{K}$ fertilizer managements, the knowledge of the $\mathrm{K}$ status of each sugarcane field is necessary; however, the common nutrient diagnosis methods by analyzing leaf or soil samples can be quite complex because these exercises usually require considerable time and technical machines and skills. Nutrient diagnosis should be as easy as possible to meet the demands of anyone who requires it. Electrical conductivity (EC) denotes a material's ability to allow the transport of an electric charge and can be easily and quickly measured with simple devices. Because of its convenience, in the sugar and sugarcane industry, EC has been intensively used to manage ash content during the milling process $[10,11]$ and in breeding programs $[9,12,13]$, as it is closely associated with ash in sugarcane juice [14-16]. Similarly, a highly positive correlation exists between EC and $\mathrm{K}$ in sugarcane juice [17]. Hence, the use of this parameter will surely facilitate the analysis of juice $\mathrm{K}$ concentration in a large number of samples.

The present study, composed of two parts, was carried out in Northeast Thailand. First, sugarcane was grown using different rates of $\mathrm{K}$ supplied with either $\mathrm{KCl}$ or $\mathrm{K}_{2} \mathrm{SO}_{4}$ to investigate the treatment effects and determine an optimum $\mathrm{K}$ range in juice in terms of both yield and quality. Second, sugarcane juice was collected at a raw sugar factory to observe variations of juice $\mathrm{K}$ and its relationship with cane quality in the study area. The aim of the study was to propose a practical method of $\mathrm{K}$ fertilizer management based on the $\mathrm{K}$ status of sugarcane juice to improve sugarcane quality and eventually sugar production in this region.

\section{Methodology}

\subsection{Sugarcane Cultivation Experiment with Various $K$ Treatments}

A pot experiment was conducted from May 23, 2017 to February 12, 2018 in a greenhouse at Mitr Phol Sugarcane Research Center Company Limited in Chaiyaphum, Thailand $\left(16^{\circ} 46^{\prime} \mathrm{N}, 102^{\circ} 12^{\prime} \mathrm{E} ; 223 \mathrm{~m}\right.$ a.s.1.). Stalks of Saccharum spp cv. Khon Kaen 3 (KK3) were cut into single-bud setts and sown in a nursery. After the first fully expanded leaves were confirmed, seedlings were transplanted into plastic pots (34 $\mathrm{cm}$ wide $\times 28 \mathrm{~cm}$ deep with a $24 \mathrm{~cm}$ base width, $18 \mathrm{~L}$ ) filled with $15 \mathrm{~kg}$ of soil mixture composed of three materials: clay soil, sandy soil, and filter cake (1:1:1 on a volume basis; $\mathrm{pH}$, 7.2; EC, $3.4 \mathrm{~S} \mathrm{~m}^{-1}$; OM, 2.2\%; exchangeable $\mathrm{K}, 232 \mathrm{mg} \mathrm{kg}^{-1}$ ). During cultivation, tillers were immediately removed after emergence and irrigation was performed with tap water through daily soil moisture evaluation to prevent water stress. Due to unknown reasons, a few plants showed inhibited growth and accordingly were removed from the experiment.

The plants were fertilized four times at 14, 84, 134, and 196 days after transplanting (DAT). Following the recommended doses in the study area, $4 \mathrm{~g} \mathrm{~N}, 2 \mathrm{~g} \mathrm{P}, 0.3 \mathrm{~g} \mathrm{Ca}$, $0.3 \mathrm{~g} \mathrm{~S}, 0.25 \mathrm{~g} \mathrm{Mg}, 2.4 \mathrm{mg} \mathrm{Fe}, 1.4 \mathrm{mg} \mathrm{Mn}, 1.4 \mathrm{mg} \mathrm{Zn,} 1 \mathrm{mg}$ $\mathrm{Cu}, 1 \mathrm{mg} \mathrm{B}$, and $1 \mathrm{mg} \mathrm{Mo} \mathrm{pot}{ }^{-1}$ in total were supplied to all the plants in the forms of urea, ammonium sulfate, ammonium phosphate, and multiple fertilizer. Along with a $\mathrm{K}$-free group, eight treatments were set up using four rates of $\mathrm{K}\left(2,10,30\right.$, and $\left.50 \mathrm{~g} \mathrm{pot}^{-1}\right)$ supplied with either $\mathrm{KCl}$ or $\mathrm{K}_{2} \mathrm{SO}_{4}$. Four replicates were prepared for each group, except those given $50 \mathrm{~g} \mathrm{~K} \mathrm{pot}^{-1}$ which had one replicate. The group names are expressed as combinations of the supplied $\mathrm{K}$ type and rate; for example, $\mathrm{KCl}-2$.

Plant height from the ground to the base of the top visible dewlap leaf, number of leaves, and soil-plant analysis development (SPAD) index of the top visible dewlap leaf using a chlorophyll meter (SPAD-502 Plus, Konica Minolta) were measured every 28 days from 13 DAT until the termination of the experiment. At 265 DAT, three to four plants for each group were cut at the ground. Stalk height, weight, and diameter were recorded after removal of parts unnecessary for sugar refining.

Clean stalks were crushed using a three-roll squeezer, and the obtained juices were roughly filtered for later measurements. Pol in juice (\%) was derived from Brix in juice $(\%)$ measured with a refractmeter (Schmidt + Haensch, ATR-P) and polarimeter reading recoded on a Schmidt + Haensch instrument (Polartronic NIR W2) following the method of International Commission for Uniform Methods of Sugar Analysis with minor modification [18]. These parameters were used to calculate Brix in cane (\%), Pol in cane $(\%)$, impurities in cane $(\%)$, and commercial cane sugar $(\mathrm{CCS}, \%)$ as follows, using an assumed figure of 13 for fiber (\%).

$$
\begin{gathered}
\text { Brix in cane }=\text { Brix in juice } \times[1-(\text { fiber }+3) / 100] \\
\text { Pol in cane }=\text { Pol in juice } \times[1-(\text { fiber }+5) / 100] \\
\text { Impurities in cane }=\text { Brix in cane }- \text { Pol in cane } \\
\text { CCS }=\text { Pol in cane }- \text { impurities in cane } / 2
\end{gathered}
$$

Sugar yield $\left(\mathrm{g} \mathrm{stalk}^{-1}\right)$ was simply calculated from stalk weight (g) and CCS (\%):

$$
\text { Sugar yield }=\text { stalk weight } \times \text { CCS } / 100
$$

Thereafter, the juice samples were stored in a freezer at - 
$20^{\circ} \mathrm{C}$ until ion analysis. After thawing, the samples were diluted 100-fold with extra-pure water and passed through a $0.45 \mathrm{~mm}$ membrane filter. Juice $\mathrm{K}$ concentration was determined by ion chromatograph (ICS-1600, Thermo Fisher Scientific). The column and the mobile phase used were Ion Pac CS12 (Thermo Fisher Scientific) and $20 \mathrm{mM}$ methane sulfonic acid solution.

After harvest, pot soils were air-dried and a 500-g subsample was taken from each pot. The soil samples were sieved $(\leq 2 \mathrm{~mm})$ and $10 \mathrm{~g}$ of each was shaken with $50 \mathrm{~mL}$ of $1 \mathrm{~N}$ ammonium acetate solution for 30 minutes. The filtrates passed through filter papers (Whatman, No. 5) were used to determine soil exchangeable $\mathrm{K}$ concentration by atomic absorption spectrometer (AA280FS, Agilent Technologies).

\subsection{Analysis of Sugarcane Juice Obtained from Raw Sugar Factory}

This analysis was conducted at Mitr Phol Phu Khiao Park in Chaiyaphum, Thailand $\left(16^{\circ} 48^{\prime} \mathrm{N}, 102^{\circ} 12^{\prime} \mathrm{E}\right.$; $228 \mathrm{~m}$ a.s.l.). Its surrounding sugarcane farmland amounts to approximately 65,000 ha and KK3 is the most dominant variety, occupying more than $80 \%$ of the area [19]. The park contains two raw sugar factories with a total crushing capacity of 40,000 tons of cane day ${ }^{-1}$. While Factory $A$ is capable of milling both manually and mechanically harvested canes, Factory B only accepts mechanically harvested ones. Both factories have small laboratories connected to the juice pipe lines, and first expressed juice (FEJ) is sent to the laboratories to evaluate its quality for cane payment purposes. To exclude any possible effects of harvesting method, juice collection was performed in the laboratory of Factory B.

In December, 2016, $50 \mathrm{~mL}$ of FEJ was taken for each cane sample and 60 samples in total were obtained (Table 1). Along with EC measurements using a PC 700 benchtop meter (Eutech Instruments) equipped with a conductivity electrode, juice $\mathrm{K}$ concentration was determined for these samples by the ion chromatography method as described previously. The data sets were used for regression analysis using EC and $\mathrm{K}$ concentration as independent and dependent variables, respectively. The linear regression equation developed was later used for the conversion of EC to juice $\mathrm{K}$ concentration.

During the 2017/18 and 2018/19 seasons, 340 and 437 samples in total were, respectively, obtained weekly throughout the crushing periods. Approximately $500 \mathrm{~mL}$ of

FEJ was taken for each cane sample to measure Brix in juice, Pol in juice, and CCS as the basic practice of the factory, following the above-described procedure [18]. Fiber was measured daily and the means of three representative cane samples ranging from 12.31 to $13.76 \%$ were used for the calculation of CCS. The parameters were all analyzed and recorded in the laboratory so that data sets were easily retrieved thereafter. The rest of the juice samples after the lab measurements were further used to measure EC with a PC 700 meter (Eutech Instruments). EC readings were then converted into $\mathrm{K}$ concentrations using the equation developed by the regression analysis performed with the 2016/17 season samples. Afterward, estimated juice $\mathrm{K}$ concentration was used to perform correlation analysis with the qualitative parameters to see how juice $\mathrm{K}$ levels affected sugarcane qualities at the factory scale.

\subsection{Statistical Analysis}

All statistical analyses were performed using the software $\mathrm{R}$ [20]. For the cultivation experiment, the mean and standard error (SE) of each group were calculated and data was subjected to two-way analysis of variance (ANOVA) to test the main effects and interactions of $\mathrm{K}$ type and $\mathrm{K}$ rate, excluding the $\mathrm{K}$-free, $\mathrm{KCl}-50$ and $\mathrm{K}_{2} \mathrm{SO}_{4}-50$ groups. In the juice analysis, Pearson's correlation coefficients were calculated between estimated juice K concentration and Brix in juice, Pol in juice, and CCS. Significances were all accepted based on a $\mathrm{P}$ value $<0.05$.

\section{Results}

\subsection{Sugarcane Cultivation Experiment with Various $K$ Treatments}

\subsubsection{Sugarcane Growth}

Plant height continued to increase throughout the experimental period (Figure 1). Treatment effects were observed from $69 \mathrm{DAT}$ in the $\mathrm{KCl}$ groups and the differences became gradually clearer in later periods. Irrespective of the $\mathrm{K}$ fertilizer type, raising $\mathrm{K}$ rates negatively affected plant height; however, the extent of the reduction caused by the $\mathrm{KCl}$ treatments was much greater. Plant height at harvest markedly differed from 103 to $178 \mathrm{~cm}$ among the $\mathrm{KCl}$ groups, whereas the $\mathrm{K}_{2} \mathrm{SO}_{4}$ groups had a smaller variance. Leaf number was about 4 at the beginning and gradually increased to reach to maximum during 150 to 209 DAT. The increments of $\mathrm{KCl}$ tended to reduce leaf number, and that of KCl-50 stayed lower with its maximum of 9. SPAD index ranged between 25 and 50 during the experiment, being affected by the fertilizations. The maximum values were recorded at 41 DAT and SPAD index started declining afterward. All the groups showed similar tendencies, except for the drastic changes seen in $\mathrm{KCl}-50$.

Table 1. Sampling information about the factory juice analysis.

\begin{tabular}{|c|c|c|c|}
\hline Season & Sampling date & Number of samples per day & Total number of samples \\
\hline $2016 / 17$ & Dec-22, Dec-24, Dec-26 (3 dates) & $17-23$ & 60 \\
\hline $2017 / 18$ & $\begin{array}{l}\text { Dec-22, Dec-28, Jan-5, Jan-12, Jan-19, Jan-29, Feb-2, Feb-9, Feb-16, Feb-26, } \\
\text { Mar-12, Mar-16, Mar-28, Apr-2 (14 dates) }\end{array}$ & $23-25$ & 340 \\
\hline $2018 / 19$ & $\begin{array}{l}\text { Nov-28, Dec-4, Dec-13, Dec-21, Dec-28, Jan-4, Jan-11, Jan-17, Jan-25, Feb-1, } \\
\text { Feb-7, Feb-15, Feb-22, Feb-28, Mar-8, Mar-15, Mar-22, Mar-29 (18 dates) }\end{array}$ & $23-25$ & 437 \\
\hline
\end{tabular}



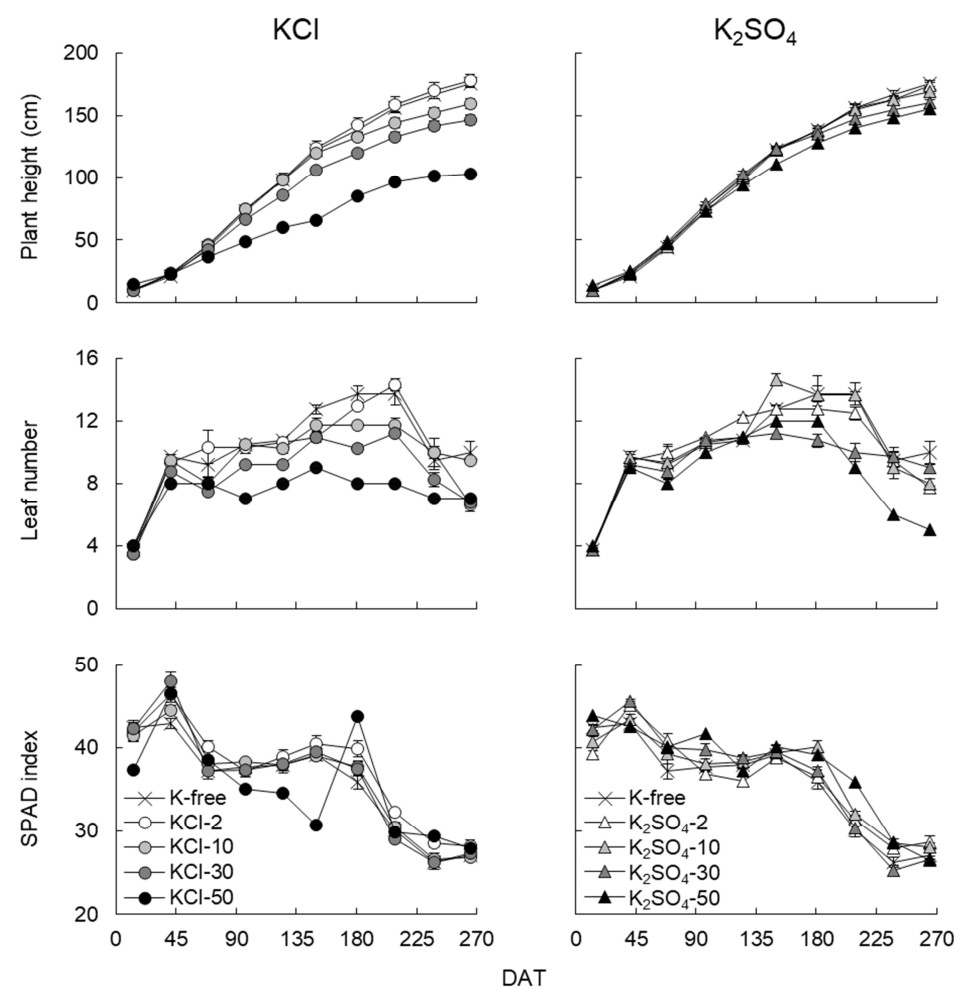

Figure 1. Changes of plant height, leaf number, and SPAD index in the $\mathrm{KCl}$ (left) and $\mathrm{K}_{2} \mathrm{SO}_{4}$ (right) groups.

Bars represent SE of the means $(n=3-4)$. Note that the graphs for both the $\mathrm{KCl}$ and $\mathrm{K}_{2} \mathrm{SO}_{4}$ groups contain the data sets of K-free.

\subsubsection{Juice K and Soil Exchangeable $K$}

Irrespective of the $\mathrm{K}$ fertilizer type, juice $\mathrm{K}$ concentration was significantly increased from 1425 to $7299 \mathrm{mg} \mathrm{L}^{-1}$ in the $\mathrm{KCl}$ groups and from 2190 to $7930 \mathrm{mg} \mathrm{L}^{-1}$ in the $\mathrm{K}_{2} \mathrm{SO}_{4}$ groups as $\mathrm{K}$ rates rose from 2 to $50 \mathrm{~g} \mathrm{pot}^{-1}$ (Figure 2). These results suggest that there were no apparent differences between $\mathrm{KCl}$ and $\mathrm{K}_{2} \mathrm{SO}_{4}$ in terms of the uptake of $\mathrm{K}$ by sugarcane. Likewise, soil exchangeable $\mathrm{K}$ concentration at harvest largely varied depending on $\mathrm{K}$ rate but not $\mathrm{K}$ fertilizer type. It is noted that large gaps were observed between the groups given 10 and $30 \mathrm{~g} \mathrm{~K} \mathrm{pot}^{-1}$, indicating that available $\mathrm{K}$ for sugarcane may have not been properly absorbed and remained in the soil when the $\mathrm{K}$ application rates were $30 \mathrm{~g}$ pot $^{-1}$ or more.
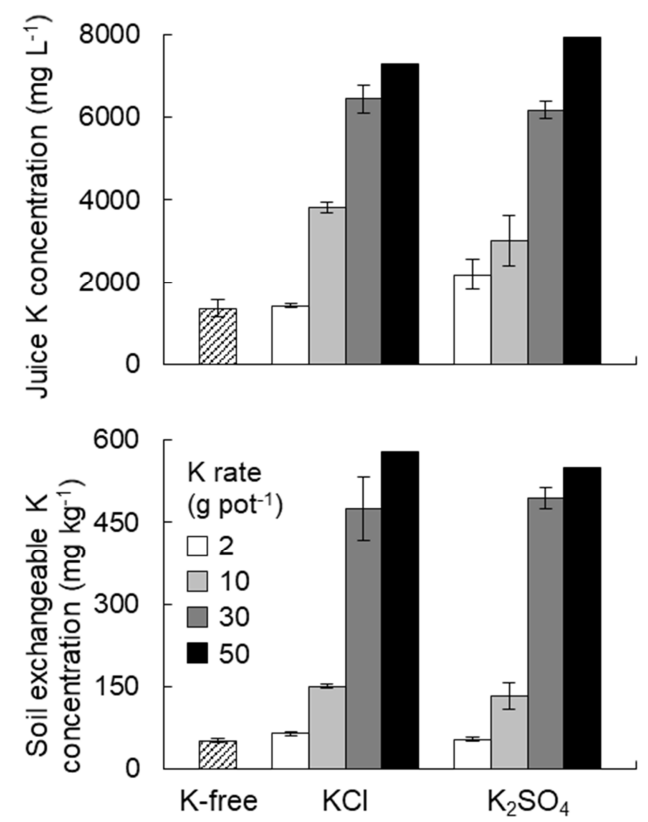

Bars represent SE of the means $(n=3-4)$.

Figure 2. Effects of type and rate of $K$ fertilizer on juice $K$ (top) and soil exchangeable $K$ (bottom) concentrations at harvest. 
Table 2. Effects of type and rate of K fertilizer on yield and quality traits at harvest.

\begin{tabular}{|c|c|c|c|c|c|c|c|}
\hline K type & K rate & Stalk length (cm) & Stalk diameter $(\mathrm{mm})$ & Stalk weight (g) & Pol in juice (\%) & $\operatorname{CCS}(\%)$ & Sugar yield $\left(\mathrm{g} \mathrm{stalk}^{-1}\right)$ \\
\hline \multirow[t]{2}{*}{ K-free } & 0 & $148 \pm 6$ & $32.3 \pm 0.7$ & $1420 \pm 34$ & $20.9 \pm 0.3$ & $16.4 \pm 0.3$ & $232 \pm 3$ \\
\hline & 2 & $150 \pm 10$ & $33.2 \pm 0.8$ & $1534 \pm 153$ & $21.2 \pm 0.1$ & $16.6 \pm 0.1$ & $255 \pm 27$ \\
\hline \multirow{4}{*}{$\mathrm{KCl}$} & 10 & $134 \pm 6$ & $33.1 \pm 0.2$ & $1290 \pm 73$ & $20.8 \pm 0.3$ & $16.2 \pm 0.2$ & $209 \pm 13$ \\
\hline & 30 & $123 \pm 8$ & $32.1 \pm 0.4$ & $1148 \pm 86$ & $19.4 \pm 0.2$ & $14.9 \pm 0.2$ & $171 \pm 15$ \\
\hline & 50 & 78 & 29.0 & 654 & 18.5 & 14.1 & 92 \\
\hline & 2 & $146 \pm 4$ & $33.4 \pm 0.5$ & $1427 \pm 72$ & $20.9 \pm 0.3$ & $16.4 \pm 0.2$ & $233 \pm 11$ \\
\hline \multirow{3}{*}{$\mathrm{K}_{2} \mathrm{SO}_{4}$} & 10 & $144 \pm 5$ & $33.3 \pm 0.3$ & $1455 \pm 71$ & $21.2 \pm 0.3$ & $16.5 \pm 0.2$ & $241 \pm 13$ \\
\hline & 30 & $137 \pm 6$ & $33.1 \pm 0.8$ & $1303 \pm 88$ & $21.0 \pm 0.2$ & $16.2 \pm 0.2$ & $212 \pm 16$ \\
\hline & 50 & 133 & 34.5 & 1278 & 20.4 & 15.8 & 202 \\
\hline \multicolumn{4}{|l|}{$\mathrm{K}$ type } & & $* *$ & $* *$ & \\
\hline \multicolumn{4}{|l|}{$\mathrm{K}$ rate } & $*$ & $* *$ & $* * *$ & $*$ \\
\hline \multicolumn{5}{|c|}{$\mathrm{K}$ type $\times \mathrm{K}$ rate } & $* *$ & $* *$ & \\
\hline
\end{tabular}

Values are means $\pm \mathrm{SE}(\mathrm{n}=3-4)$, except for $\mathrm{KCl}-50$ and $\mathrm{K}_{2} \mathrm{SO}_{4}-50(\mathrm{n}=1) . *$, **, and *** denote significances at the $5 \%, 1 \%$, and $0.1 \%$ levels, respectively (two-way ANOVA). Note that $\mathrm{K}$-free, $\mathrm{KCl}-50$, and $\mathrm{K}_{2} \mathrm{SO}_{4}-50$ were excluded from the statistical analysis.

\subsubsection{Sugarcane Yield and Quality}

Although the main effect was insignificant, increasing $\mathrm{K}$ rates caused certain reductions of stalk height, especially in the $\mathrm{KCl}$ groups (Table 2). Similar results were acquired in stalk weight with a significant main effect of $\mathrm{K}$ rate, whereas stalk diameter was likely to be less affected. The highest stalk height and weight were obtained in $\mathrm{KCl}-2$, followed by $\mathrm{K}$ free, $\mathrm{K}_{2} \mathrm{SO}_{4}-2$, and $\mathrm{K}_{2} \mathrm{SO}_{4}-10$. Surprisingly, $\mathrm{KCl}-10$, $\mathrm{KCl}-30$, and $\mathrm{K}_{2} \mathrm{SO}_{4}-30$ showed lower values in these parameters than $\mathrm{K}$-free. Quality traits, as well as the yield components, were markedly affected by the $\mathrm{K}$ treatments. Increasing $\mathrm{KCl}$ rates caused negative impacts, reducing Pol in juice from 21.2 to $18.5 \%$ and CCS from 16.6 to $14.1 \%$. On the other hand, raising $\mathrm{K}_{2} \mathrm{SO}_{4}$ rates hardly impaired the quality traits. As a result of the two-way ANOVA, the $\mathrm{K}$ type $\times \mathrm{K}$ rate interactions for Pol in juice and CCS were significant at the $1 \%$ and $0.1 \%$ levels, respectively. Sugar yield was calculated from stalk weight and $\mathrm{CCS}$. $\mathrm{KCl}-2$ which recorded the highest stalk weight and CCS accordingly gained maximum sugar yield of $255 \mathrm{~g} \mathrm{stalk}^{-1}$ across all. Along with increasing $\mathrm{K}$ rates, substantial reductions of sugar yield were observed in the $\mathrm{KCl}$ groups since $\mathrm{CCS}$ was also remarkably reduced. Meanwhile, among the $\mathrm{K}_{2} \mathrm{SO}_{4}$ groups, $\mathrm{K}_{2} \mathrm{SO}_{4}-10$ showed the greatest sugar yield. Still, the main effect of $\mathrm{K}$ rate was revealed to be significant, implying that higher $\mathrm{K}$ rates led to lower sugar yields. Not statistically analyzed due to the small numbers of replicates, however, $\mathrm{KCl}-50$ exhibited far smaller values for all parameters as compared to the other groups, whereas $\mathrm{K}_{2} \mathrm{SO}_{4}-50$ resulted in lesser degrees of reduction and showed greater values than $\mathrm{KCl}-30$. Large gaps between the $50 \mathrm{~g} \mathrm{~K}$ groups again demonstrated the disadvantages of excessive use of $\mathrm{KCl}$ over $\mathrm{K}_{2} \mathrm{SO}_{4}$.

\subsubsection{Relationships Between Juice K and Sugarcane Yield and Quality Traits}

Figure 3 comprises of scatter diagrams to illustrate the three relationships between juice $\mathrm{K}$ concentration and stalk weight, CCS, and sugar yield. For all of these, maximum values were obtained in $\mathrm{KCl}-2$ with a juice $\mathrm{K}$ concentration of $1500 \mathrm{mg} \mathrm{L}^{-1}$. The second-order polynomial trendlines for the $\mathrm{KCl}$ groups elucidate that these parameters tended to decline as juice $\mathrm{K}$ concentrations became higher than 2000 $\mathrm{mg} \mathrm{L}{ }^{-1}$. By contrast, the plants treated with $\mathrm{K}_{2} \mathrm{SO}_{4}$ showed lesser degrees of reduction as $\mathrm{K}$ rates rose; as a result, sugar yield was maximized in $\mathrm{K}_{2} \mathrm{SO}_{4}-10$ with a $\mathrm{K}$ concentration around $3000 \mathrm{mg} \mathrm{L}^{-1}$ among the $\mathrm{K}_{2} \mathrm{SO}_{4}$ groups.
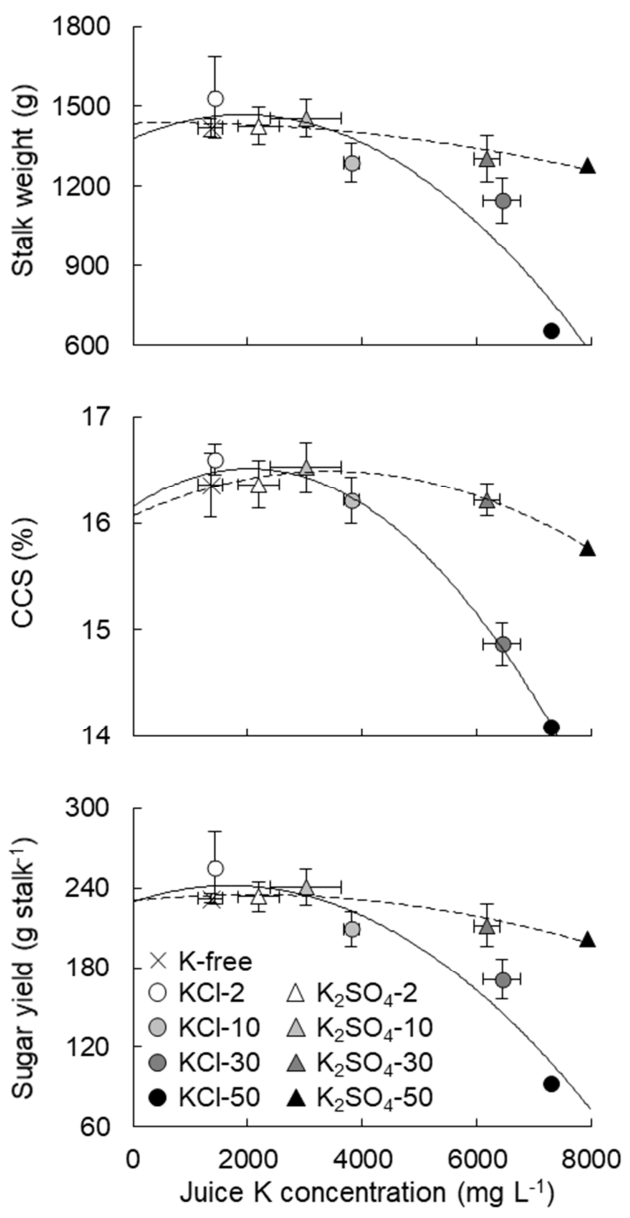

Figure 3. Relationships between juice $K$ concentration and stalk weight (top), CCS (middle), and sugar yield (bottom).

Bars represent $\mathrm{SE}$ of the means $(\mathrm{n}=3-4)$. The second-order polynomial trendlines for the $\mathrm{KCl}$ (solid) and $\mathrm{K}_{2} \mathrm{SO}_{4}$ (broken) groups including $\mathrm{K}$-free are shown in the graphs. 


\subsection{Analysis of Sugarcane Juice Obtained from Raw Sugar Factory}

\subsubsection{Regression Analysis Between Juice K and EC}

The 60 FEJ samples collected in December, 2016 possessed wide ranges of EC values from 603 to $1748 \mathrm{mS} \mathrm{m}^{-}$ ${ }^{1}$ and $\mathrm{K}$ concentrations from 1083 to $3353 \mathrm{mg} \mathrm{L}^{-1}$, meaning that the sample collection was successfully performed to be used for regression analysis. The data sets of EC measured with a benchtop meter and $\mathrm{K}$ concentration determined by ion chromatograph were then plotted in a scatter diagram (Figure 4). It is clear that EC was highly associated with juice $\mathrm{K}$ concentration. According to the regression analysis applied between juice $\mathrm{K}$ concentration $\left(\mathrm{mg} \mathrm{L}^{-1}\right)$ and $\mathrm{EC}\left(\mathrm{mS} \mathrm{m}^{-1}\right)$, a linear equation was yielded as follows:

$\mathrm{K}$ concentration $=1.9007 \times \mathrm{EC}-88.677(6)$

The coefficient of determination $\left(\mathrm{R}^{2}\right)$, which indicates the quality of its fit to the data, was calculated to be 0.9209 , implying that $\mathrm{EC}$ can explain $92 \%$ of the variation in juice $\mathrm{K}$ concentration of the obtained samples. The SE of the analysis was 182.5 , which corresponds to as much as $8.08 \%$ of the average $\mathrm{K}$ concentration of $2259 \mathrm{mg} \mathrm{L}^{-1}$. The equation was also highly significant with an $\mathrm{F}$ ratio of 998.7 at the $0.1 \%$ level.

\subsubsection{Variability in Juice $K$}

Juice K concentration was then estimated from EC for all the $2017 / 18$ and 2018/19 season samples by applying the equation developed in the previous section. The means \pm standard deviations of the estimated juice $\mathrm{K}$ concentrations were calculated to be $2143 \pm 497$ and $2279 \pm 523 \mathrm{mg} \mathrm{L}^{-1}$ in the $2017 / 18$ and $2018 / 19$ seasons, respectively. The histogram tells that the estimated juice $\mathrm{K}$ concentration were distributed within $4000 \mathrm{mg} \mathrm{L}^{-1}$, with a peak range of $2000 \leq$ $\mathrm{K}<2500 \mathrm{mg} \mathrm{L}^{-1}$ and that similar distribution patterns were observed in both years (Figure 5). The percentages of the samples with estimated juice $\mathrm{K}$ concentrations above 2000 $\mathrm{mg} \mathrm{L}^{-1}$ were 60.3 and $65.9 \%$ in the $2017 / 18$ and $2018 / 19$ seasons, respectively.

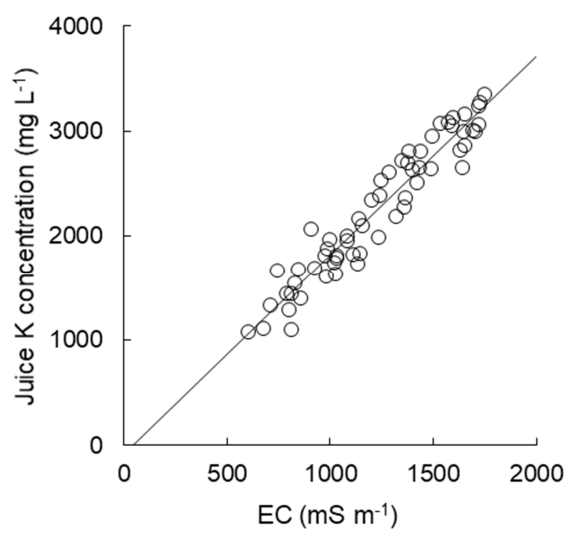

Figure 4. Juice K concentration plotted against EC for the 2016/17 season samples.

The linear trendline is shown in the graph. The $\mathrm{R}^{2}$ value and $\mathrm{SE}$ of the analysis were 0.9209 and 182.5 , respectively. The equation was statistically significant $(\mathrm{n}=60, \mathrm{~F}=998.7, \mathrm{P}<0.001)$.

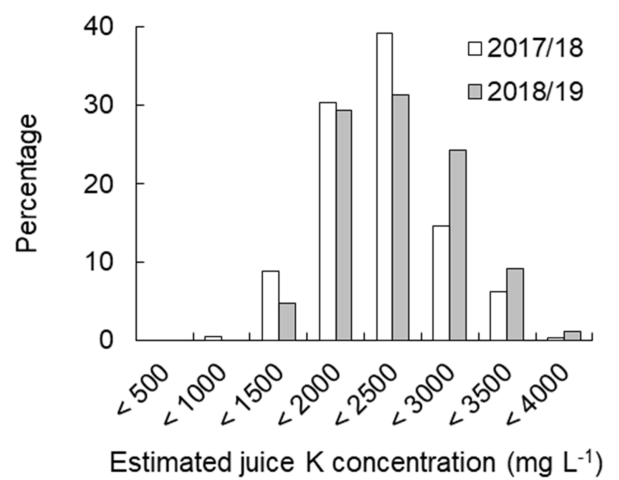

Figure 5. Distributions of juice $K$ concentration estimated from EC for the $2017 / 18(n=340)$ and $2018 / 19(n=437)$ season samples.

\subsubsection{Relationships Between Juice K and Sugarcane Quality Traits}

The correlation analyses revealed that Brix in juice (correlation coefficient $(r)=-0.4106)$, Pol in juice $(r=$ $0.4470)$ and $\operatorname{CCS}(\mathrm{r}=-0.4645)$ were all significantly negatively correlated with estimated juice $\mathrm{K}$ concentration at the $0.1 \%$ levels. Among these, CCS was plotted against estimated juice $\mathrm{K}$ concentration to visually grasp the relationship at the factory scale (Figure 6). The means \pm standard deviations of CCS were $13.94 \pm 1.04$ and $13.78 \pm$ $1.30 \%$ in the $2017 / 18$ and $2018 / 19$ seasons, respectively. Although the trend was not sufficiently clear, it is seen that CCS linearly declined as juice $\mathrm{K}$ concentration increased. Extremely low CCS values below $11 \%$ were observed particularly in the $2018 / 19$ season, accompanied with high $\mathrm{K}$ concentrations above $2000 \mathrm{mg} \mathrm{L}^{-1}$. The average CCS value of the overall samples with estimated juice $\mathrm{K}$ concentrations below $2000 \mathrm{mg} \mathrm{L}^{-1}$ was $14.40 \%$, while that with juice $\mathrm{K}$ above $2000 \mathrm{mg} \mathrm{L}^{-1}, 13.54 \%$, was significantly lower.

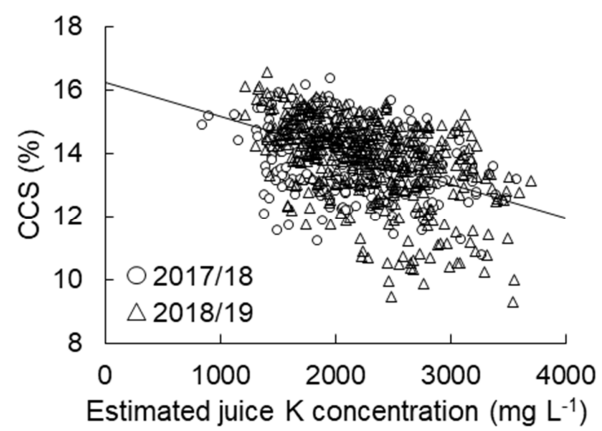

Figure 6. Relationship between estimated juice K concentration and CCS for the 2017/18 $(n=340)$ and $2018 / 19(n=437)$ season samples.

The linear trendline for the overall samples is shown in the graph. The relationship was statistically significant $(n=777, r=-0.4645, P<0.001)$.

\section{Discussion}

From the cultivation experiment using a commercial Thai variety, $\mathrm{KK} 3$, we found that raising $\mathrm{KCl}$ rates gave considerably negative impacts on Pol in juice and CCS, whereas the effects of the $\mathrm{K}_{2} \mathrm{SO}_{4}$ treatments were comparatively negligible. The output of the two-way ANOVA 
also revealed the $\mathrm{K}$ type $\times \mathrm{K}$ rate interactions for these parameters to be statistically significant, meaning that $\mathrm{KCl}$ and $\mathrm{K}_{2} \mathrm{SO}_{4}$ caused different effects on sugarcane quality. These results concur with the previous study that significant reductions of sucrose concentration in juice were caused by higher doses of $\mathrm{KCl}$ but not of $\mathrm{K}_{2} \mathrm{SO}_{4}$ [6]. In our present study, besides juice quality, sugarcane growth and yield traits such as stalk height and weight were also substantially decreased by the $\mathrm{KCl}$ applications. This is partially contrary to their finding that clear treatment effects on yield components were not confirmed. This was probably attributed to varietal difference in responses to raising $\mathrm{KCl}$ rates since the uptake of $\mathrm{K}$ is also affected by genetic background [21, 22]. Watanabe et al. subjected several sugarcane varieties to a $\mathrm{KCl}$-abundant condition and reported that its effects on the yield and quality as well as juice $\mathrm{K}$ concentration significantly varied across the varieties [23]. These imply that KK3, the variety used for the present study, was more sensitive to changes of $\mathrm{KCl}$ dose in point of quantitative traits.

Other findings from the cultivation experiment are that the plants treated with $2 \mathrm{~g} \mathrm{~K}$ with $\mathrm{KCl}$ exhibited the best results in terms of both quantitative and qualitative traits and that stalk weight, CCS, and sugar yield all tended to decline with juice $\mathrm{K}$ concentrations exceeding $2000 \mathrm{mg} \mathrm{L}^{-1}$ in the $\mathrm{KCl}$ groups. Therefore, this level is considered the threshold of juice $\mathrm{K}$ to impair the yield and quality when $\mathrm{KK} 3$ is fertilized with $\mathrm{KCl}$. Given that $\mathrm{KCl}$ is the major source of $\mathrm{K}$ fertilizer used in agriculture, juice $\mathrm{K}$ concentration should be kept lower than this level in order to prevent any losses in sugar yield. Nevertheless, it was found that, based on the results of the factory juice analysis, $60.3 \%$ and $65.9 \%$ of the analyzed juice samples possessed $\mathrm{K}$ concentrations above $2000 \mathrm{mg} \mathrm{L}^{-1}$ in the 2017/18 and 2018/19 crushing seasons, respectively. Assuming that the study area were covered with KK3 only, it would be deduced that more than $60 \%$ of sugarcane crops have been receiving more $\mathrm{K}$ than they need. Meanwhile, this estimation would be false if $\mathrm{K}_{2} \mathrm{SO}_{4}$ were supplied in the actual fields instead of $\mathrm{KCl}$. In the cultivation experiment, $\mathrm{K}_{2} \mathrm{SO}_{4}-10$ gained the highest sugar yield among the $\mathrm{K}_{2} \mathrm{SO}_{4}$ groups with a $\mathrm{K}$ concentration of $3000 \mathrm{mg} \mathrm{L}^{-1}$, which spanned the majority of the juice $\mathrm{K}$ concentrations observed in the factory juice analysis. Although $\mathrm{K}_{2} \mathrm{SO}_{4}$ is not as prevalent as $\mathrm{KCl}$ and normally is not applied for sugarcane production today, our study could prove the use of this $\mathrm{K}$ fertilizer worth considering.

It would be of great interest to associate juice $\mathrm{K}$ concentration with quantitative parameters such as cane yield at the factory scale. Unfortunately, we were unable to retrieve detailed sample information from the factory; hence, correlation analysis was performed only for qualitative parameters. The relationship between estimated juice $\mathrm{K}$ concentration and CCS would certainly be clearer if minor varieties other than KK3 were eliminated and/or if data sets were assigned to categories of plant and ratoon canes. Still, the relationship was significantly negative with an $r$ value of -0.4645 , and the sample group with juice K higher than 2000 $\mathrm{mg} \mathrm{L}^{-1}$ showed a $0.86 \%$ decrease in CCS on average, which could advocate the results of the $\mathrm{KCl}$ treatments in the cultivation experiment. Similar relationships between inorganic salts in juice and sugarcane quality have also been reported by other researchers. In Australia, the concentrations of $\mathrm{K}^{+}, \mathrm{Cl}^{-}$, and ash in juice were negatively correlated with Pol, purity, and CCS in juice [24]. In addition, the relationships between ash and CCS were all significantly negative for several varieties [11]. Watanabe et al. conducted sugarcane juice analysis in Japan over 3 years and demonstrated that $\mathrm{K}^{+}$and $\mathrm{Cl}^{-}$concentrations as well as EC were always negatively correlated with sucrose concentration in juice and the relationships were mostly significant regardless of variety and crop age [17]. Taking these together with the results of our cultivation experiment, it could be indicated that impairments of sugarcane quality have probably been occurring in the actual fields of the study area. Therefore, appropriate practices for $\mathrm{K}$ fertilizer management should contribute to achieving better cane quality and consequently greater sugar production.

In Thailand, a number of fertilizer products are currently available at markets and fertilizer applications for sugarcane production vary from farm to farm. For instance, according to the recommendations by Thai Central Chemical Public Company Limited, 15 to $47 \mathrm{~kg} \mathrm{~K} \mathrm{ha}^{-1}$ and 45 to $66 \mathrm{~kg} \mathrm{~K} \mathrm{ha}^{-1}$ are to be applied at planting and at 2 to 3 months thereafter, respectively, using compound fertilizers containing 6 to $21 \%$ of $\mathrm{K}$ in the form of $\mathrm{KCl}$ [25]. As our study suggested, information on juice $\mathrm{K}$ concentration obtained from juice analysis will be of great help in selection of $\mathrm{K}$ fertilizer for the next cultivation season: those with lower percentages of $\mathrm{K}$ should be selected in a year following one when the $\mathrm{K}$ concentration in juice is found to be higher than $2000 \mathrm{mg} \mathrm{L}^{-1}$. These practices would not only improve sugarcane quality but also alleviate the environmental burden and save fertilizer cost caused by excessively given K. Alternatively, the use of $\mathrm{K}_{2} \mathrm{SO}_{4}$ might be a solution for the high $\mathrm{K}$ problems; yet, the practice of this method awaits further study until it has been proven economically effective, considering that $\mathrm{KCl}$ is the cheapest K source [26]. Another important K source for sugarcane cultivation is vinasse, which is a liquid waste from the distillation process of ethanol production and is rich in macro- and micro-nutrients, mainly K [27]. In the study area, it is estimated that approximately $25 \%$ of the sugarcane growers apply vinasse to their fields [28]. Containing large quantities of $\mathrm{K}$ and $\mathrm{Cl}$, vinasse is likely to have similar functions to $\mathrm{KCl}$ and thus could be a factor that reduces sugarcane quality as our study demonstrated. Nevertheless, the growers conventionally apply the same dose of $\mathrm{K}$ with chemical fertilizers, not knowing its possible risks. Consideration should be given to $\mathrm{K}$ application especially when associated with vinasse fertigation.

In the present study, we analyzed a limited number of juice samples which covered only a few percentages of the total cane samples processed at the factory. Even though the EC measurement method described in this paper is useful and readily applicable, it will not be practical to manually 
analyze FEJ at all times during milling operation. Kingston and Kirby and Kingston have installed industrial conductivity meters to juice pipe lines in order to observe continuous changes of juice conductivity [10, 11]. By applying this idea, it will be possible to automatically obtain an EC reading for every juice sample, and thereby we are currently working on the installation of a conductivity monitor in the factory. To efficiently utilize the results obtained from the present study, systems to provide growers with feedback on the juice $\mathrm{K}$ status and actual recommended dose of each sugarcane field are desirable and should be developed in the future.

\section{Conclusion}

From the present study, it was revealed that sugarcane growth, yield, and quality were reduced by excessive uses of $\mathrm{KCl}$ particularly as juice $\mathrm{K}$ concentration became higher than $2000 \mathrm{mg} \mathrm{L}^{-1}$. Number of growers in the study area potentially need improvements in $\mathrm{K}$ management and the suggested diagnosis method through juice analysis at factory scale could greatly facilitate the selection of $\mathrm{K}$ fertilizer for next season. Whether the fertilizer management practices based on this method certainly give positive impacts on sugarcane should be examined so that growers and millers will realize its importance and usefulness.

\section{Acknowledgements}

The authors are grateful to Dr. Yoshinobu Kawamitsu at the Department of Agriculture, University of the Ryukyus in Okinawa, Japan, for allowing us to use the ion chromatograph for the measurements of juice $\mathrm{K}$.

\section{Conflict of Interest}

The authors declare that there is no conflict of interest.

\section{References}

[1] Prajapati K, Modi H A, 2012. The importance of potassium in plant growth - a review. Indian J. Plant Sci., 1: 177-186.

[2] Bartholomew R P, Janssen G, 1929. Luxury consumption of potassium by plants and its significance. J. Am. Soc. Agron., 21: 751-765.

[3] Ng Kee Kwong, K F, 2002. The effects of potassium on growth, development, yield and quality of sugarcane. In Potassium for Sustainable Crop Production, Proceedings of the International Symposium on the Role of Potassium in Nutrient Management for Sustainable Crop Production in India, New Delhi, India, 3-5 December 2001, 430-444.

[4] Mayer J H, Wood R A, 2001. The effects of soil fertility and nutrition on sugarcane quality: a review. Proceedings of the South African Sugar Technologists' Association, Durban, South Africa, 31 July-August 3 2001, 75: 242-247.

[5] Wood A W, 2004. Schroeder, B. Potassium: a critical role in sugarcane production, particularly in drought conditions. Proceedings of Australian Society of Sugar Cane Technologists, Brisbane, Australia, 4-7 May 2004, 26: (CDROM), 11 pp.

[6] Watanabe K, Fukuzawa Y, Kawasaki S-I, Ueno M, Kawamitsu Y, 2016. Effects of potassium chloride and potassium sulfate on sucrose concentration in sugarcane juice under pot conditions. Sugar Tech, 18: 258-265.

[7] Watanabe K, Tominaga J, Yabuta S, Takaragawa H, Suwa R, Ueno M, Kawamitsu Y, 2017. Effects of different kinds of potassium and chloride salts on sugarcane quality and photosynthesis. Sugar Tech, 19: 378-385.

[8] Kafkafi U, 2001. Preface. In Potassium and Chloride in Crops and Soils: the Role of Potassium Chloride Fertilizer in Crop Nutrition. Johnston A E, Eds. International Potash Institute: Basel, Switzerland, 9.

[9] Jackson P A, Schroeder B L, Rattey A R, Wood A, O'Shea M $\mathrm{G}, 2008$. Management of ash/impurity ratio in sugarcane: relative effects of genotypes, and $\mathrm{N}$ and $\mathrm{K}$ fertilizer rates. Aust. J. Agr. Res., 59: 795-801.

[10] Kingston G, Kirby L K, 1979. Ash in juice - a supply area survey. Proceedings of Australian Society of Sugar Cane Technologists, Mackay, Australia, 30 April-4 May 1979, 1: 61-69.

[11] Kingston G, 1982. Ash in first expressed cane juice at Rocky Point - II. Effects of geography and varieties. Proceedings of Australian Society of Sugar Cane Technologists, Townsville, Australia, 19-23 April 1982, 4: 19-22.

[12] Hogarth D M, 1983. The inheritance of ash in juice from sugar cane. Mill. Effic. Technol., 23 pp.

[13] Mullins R T, Roach B T, 1985. Genetic origins of ash in sugarcane juice. Proceedings of Australian Society of Sugar Cane Technologists, Bundaberg, Australia, 29 April-3 May 1985, 7: 43-51.

[14] Kirby L K, Kingston G, 1978. Inorganic ash and cane topping. Proceedings of Queensland Society of Sugar Cane Technologists, Townsville, Australia, 17-21 April 1978, 45: 133-138.

[15] Olson B C, 2002. Relationship between juice properties and ash in sugar. Proceedings of Australian Society of Sugar Cane Technologists, Cairns, Australia, 29 April-2 May 2002, 24: (CD-ROM), 9 pp.

[16] Sens V, Corcodel L, Leveau A, 2005. Monitoring cane quality with quick and cheap analytical indicators on cane juice. Proceedings of International Society of Sugar Cane Technologists, Guatemala City, Guatemala, 30 January-4 February 2005, 25: 164-169.

[17] Watanabe K, Nakabaru M, Taira E, Ueno M, Kawamitsu Y, 2016. Relationships between nutrients and sucrose concentrations in sugarcane juice and use of juice analysis for nutrient diagnosis in Japan. Plant Prod. Sci., 19: 215222 .

[18] International Commission for Uniform Methods of Sugar Analysis, 2011. Method GS5/7-1 (2011) The determination of Pol (Polarisation), Brix and fibre in cane and bagasse by the wet disintegrator method with lead subacetate - official. In Methods Book (2011). Verlag Dr. Albert Bartens KG: Berlin, Germany, 8 pp. 
[19] Wirojsirasak W, 2019. Mitr Phol Sugarcane Research Center Company Limited, Phukhiao, Chaiyaphum, Thailand. Personal communication.

[20] R Core Team, 2018. R: A language and environment for statistical computing. R Foundation for Statistical Computing: Vienna, Austria.

[21] Stevenson D M, McGrath G J, Statham M K, 1970. A potash survey in the Pioneer mill area. Proceedings of Queensland Society of Sugar Cane Technologists, Mackay, Australia, 8-14 April 1970, 37: 39-49.

[22] Irvine J E, 1981. Variations of non-sucrose solids in sugarcane, I. Potassium. Proceedings of American Society of Sugar Cane Technologists 1979 Meetings, 9 (New Series): 5861 .

[23] Watanabe $\mathrm{K}$, Takaragawa $\mathrm{H}$, Maekawa M, Matsubara $\mathrm{T}$, Kawamitsu Y, 2017. Sugarcane cultivar differences in ion and sugar accumulation characteristics in response to high $\mathrm{KCl}$ application. Abstracts of the 243rd Meetings of Crop Science Society of Japan, Tokyo, Japan, 29-30 March 2017, 243: 13.
[24] Kingston G, 1982. Ash in first expressed cane juice at Rocky Point - I. factors affecting the inorganic composition of juices. Proceedings of Australian Society of Sugar Cane Technologists, Townsville, Australia, 19-23 April 1982, 4: 1117.

[25] Thai Central Chemical Public Company Limited, 2019. Our Products, Sugarcane Fertilizer http://www.tccethai.com/en/our-products/sugarcane-fertilizer Accessed on 26 August 2019.

[26] Magen H, 1996. Potassium chloride in fertigation. Proceedings of 7 th International Conference on Water and Irrigation, Tel Aviv, Israel, 13-16 May 1996, 7: 7 pp.

[27] Lucas T F, Isabella J R, Marcelo L G, 2017. Fertirrigation with sugarcane vinasse: foreseeing potential impacts on soil and water resources through vinasse characterization. J Environ. Sci. Heal. A, 52: 1063-1072.

[28] Khongsanun T, 2019. Mitr Phol Sugarcane Research Center Company Limited, Phukhiao, Chaiyaphum, Thailand. Personal communication. 